\title{
ALVAR AALTO
}





\section{ALVAR AALTO}

Band I 1922-1962

Volume I 1922-1962 
Traduction française: H.R. Von der Mühll, architecte, Lausanne

English translation: William B. Gleckmann, Architect, New York

\section{Photographen}

Heikki Havas, Helsinki (Villa Carré, Kultuuritalo, Museum Reval, Muuratsalo, Volkspensionsanstalt, Inter-

bau, Vuoksenniska, Jyväskylä, Rautatalo); Heidersberger, Schloß Wolfsburg (Wolfsburg); Hugo P. Herdeg,

Zürich (Finnischer Pavillon der Pariser Weltausstellung); H. Iffland, Helsinki (Kleinstwohnung, Paimio);

Pertti Ingervo, Helsinki (Enso-Gutzeit Oy., Jyväskylä, Vuoksenniska); Kleine-Tebbe, Bremen (Hochhaus

Bremen); Pekka Laurila, Helsinki (Villa Carré); Eino Käkinen, Helsinki (Villa Mairea, Rautatalo, Säynätsalo);

Kalevi A. Mäkinen, Seinäjoki (Seinäjoki); Federico Marconi, Udine (Enso-Gutzeit Oy.); Leonardo Mosso,

Turin (Atelier); Roos, Helsinki (Kapelle Malm, Sunila); Lisbeth Sachs, Zürich (M.I.T. Dormitory); Ezra Stoller,

New York (Pavillon New York); Karl und Helma Toelle, Berlin-Lichterfelde (Interbau); Valokuva Oy., Kolmio

(Möbelstudien, Artek, Kuopio, Villa Mairea, Säynätsalo); Gustav Velin, Turku (Turun Sanomat, Bibliothek

Viipuri, Paimio).

Library of Congress Cataloging-in-Publication data

A CIP catalog record for this book has been applied for at the Library of Congress.

Bibliographic information published by the German National Library

The German National Library lists this publication in the Deutsche Nationalbibliografie; detailed bibliographic data are available on the Internet at http://dnb.dnb.de.

This work is subject to copyright. All rights are reserved, whether the whole or part of the material is concerned, specifically the rights of translation, reprinting, re-use of illustrations, recitation, broadcasting, reproduction on microfilms or in other ways, and storage in data banks. For any kind of use, permission of the copyright owner must be obtained.

\section{First edition 1963}

Sixth uncorrected reprint 2014

(C) 1995 Birkhäuser Verlag $\mathrm{GmbH}$, Basel

P.O. Box 44, 4009 Basel, Switzerland

Part of Walter de Gruyter $\mathrm{GmbH}$, Berlin/Boston

Printed on acid-free paper produced from chlorine-free pulp. TCF $\infty$

Printed in Germany

$\begin{array}{ll}\text { ISBN 978-3-7643-5500-5 } & \text { (Volume I) } \\ \text { ISBN 978-3-7643-5501-2 } & \text { (Volume II) } \\ \text { ISBN 978-3-7643-5502-9 } & \text { (Volume III) } \\ \text { ISBN 978-3-7643-5517-3 } & \text { (Volume I-III, Set) }\end{array}$

This publication is also available as an e-book.

www.birkhauser.com 